\title{
The Penumbra of Weimar Political Culture: Pacifism, Feminism, and Social Democracy
}

Shelley Rose

Cleveland State University, shelley.rose@csuohio.edu

Follow this and additional works at: https://engagedscholarship.csuohio.edu/clhist_facpub

Part of the European History Commons

How does access to this work benefit you? Let us know!

\section{Publisher's Statement}

This is the accepted version of the following article: "The Penumbra of Weimar Political Culture: Pacifism, Feminism, and Social Democracy", which has been published in final form at http://onlinelibrary.wiley.com/doi/10.1111/j.1468-0130.2011.00701.x/abstract

\section{Repository Citation}

Rose, Shelley, "The Penumbra of Weimar Political Culture: Pacifism, Feminism, and Social Democracy" (2011). History Faculty Publications. 88.

https://engagedscholarship.csuohio.edu/clhist_facpub/88

This Article is brought to you for free and open access by the History Department at EngagedScholarship@CSU. It has been accepted for inclusion in History Faculty Publications by an authorized administrator of EngagedScholarship@CSU. For more information, please contact library.es@csuohio.edu. 


\section{The Penumbra of Weimar Political Culture: Pacifism, Feminism, and Social DEMOCRACY}

by Shelley E. Rose

This article offers a new reading of Germany's complex political culture, exploring the contributions of pacifists, international feminists, and Social Democrats as proactive, yet marginalized, participants in Weimar-era politics. Through a series of historical events including the No-More-War protests, international education courses, pacifist reading sessions, and a transnational peace exhibit, the author demonstrates dynamic exchanges between party and informal politics on the political Left. This interaction, as well as expanding transnational networks and awareness, opened new political spaces for peace activism in the Weimar Republic, the effects of which still endure today.

The disappointing end of the Weimar Republic in the rise of National Socialism has inspired a broad body of scholarship on German militarism that downplays the influence of pacifism in German political culture. Historian Richard Bessel, for example, asserts that pacifism "found no appreciable echo in Weimar politics." Furthermore, he argues it "remains one of the most telling characteristics of the political culture of inter-war Germany that pacifism failed to make a significant impact after so awful and senseless an armed conflict." ${ }^{\prime 1}$ Bessel pits the failure of pacifism against the appeal of militarism in Weimar Germany, emphasizing pacifists' marginal position in a political culture dominated by conservative institutions and the tacit acceptance of violence. Historian Jennifer Anne Davy addresses these arguments in her analysis of Weimar antimilitarists. Acknowledging the "broad spectrum of [Weimar] political factions" which embraced masculine and militaristic rhetoric, Davy draws attention to the urgent need to reevaluate the 
role of pacifism during the Weimar Republic. ${ }^{2}$ Indeed, militarism comprised only one thread of continuity in a Weimar tapestry that also contained nationalism, communism, mainstream pacifism, Social Democracy, and international feminism. By emphasizing the dominance of militarism in Weimar political culture, Bessel and others obscure the significance of noncommunist Left-wing groups, many of which had rich foundations in the late nineteenth century and resurfaced as active participants in West Germany's post-World War II democracy.

This investigation focuses on four case studies of Weimar-era peace activism: the 1920s No-More-War (Nie-Wieder-Krieg) protests, Women's International League for Peace and Freedom (WILPF) international education courses, German Pacifist Student Union (Deutscher Pazifistischer Studentenbund-DPSt) public reading sessions from 1925 to 1927 , and the 1927 transnational peace exhibit "Peace Movements and Peace Activism in All Countries," which toured in five German cities. Each example represents a crossroads between national politics and transnational networks exemplified by individual efforts to participate in both arenas. ${ }^{3}$ These educational events reflect the ambitions of pacifists, feminists, and Social Democrats to be proactive participants in Weimar political culture as they mobilized around issues of peace and established provisional traditions of cooperation between party and periphery groups.

\section{NEGOTIATING WEIMAR POLITICAL SPACE}

I draw on a core/penumbra model developed by early modern historians Laurence Brockliss and Colin Jones to better understand the complicated political relationship between pacifism and Social Democracy. ${ }^{4}$ In their understanding, the core represented formal medical institutions in early modern France and the penumbra were formed by various healers, so-called quacks, and other social actors at the edge of the institutional core. The authors employ the term "penumbra" instead of "periphery" to emphasize permeability and exchange between the core and marginalized participants in the medical world. The noncommunist Left within Weimar political culture can be considered in similar terms. The core/penumbra model implies a constant intermingling of ideas, members, and strategies between formal party politics and grassroots activism. This framework facilitates the evaluation of Social Democrats, pacifists, and feminists within national 
political culture while at the same time, it emphasizes moments of cooperation and conflict between mainstream party members and supporters of grass-roots activism. Transnational networks and ideas also were more freely exchanged and fostered at the edge of the formal party system.

The complex relationship of the German Social Democratic Party (Sozialdemokratische Partei Deutschlands-SPD), commonly known as a "peace party," to the peace movement makes the German Left a particularly suitable illustration for this new investigation into the development of transnational awareness within political culture. Though ideologically compatible, cooperation between pacifists and Social Democrats was often stymied by class and political tensions before and during the Weimar era. Dieter Riesenberger, for example, describes late nineteenth and early twentieth century tensions between the party and the predominantly bourgeois peace movement well. Riesenberger asserts that party leaders saw the Socialist Second International fundamentally as an "anti-war movement." This point is reinforced by Wolfram Wette's observation that Social Democrats tended toward basically pacifist politics. Mutual distrust obstructed coordinated efforts between the two, however, and Riesenberger contends pre-World War I Social Democratic cooperation with bourgeois pacifists was simply not feasible. ${ }^{5}$ Indeed, the party's subsequent votes for war credits revealed the distance between Social Democratic politics and peace politics during World War I. This conflict led independent Social Democrats, many of whom were pacifists, to split from the SPD and form the Independent Social Democratic Party (Unabhängige Sozialdemokratische Deutschlands- USPD). The two parties remained separate until 1922, setting the institutional framework for the Weimar Left. ${ }^{6}$

Although the official relationship between party and movement during the Weimar Republic remained tenuous, many individual pacifists recognized the SPD as the best chance for party political support. Traditional socialist commitments to international reconciliation and the fact that many pacifists sympathized with, or were members of, the SPD created a strong affinity and fostered exchange between the two groups. ${ }^{7}$ In her study of women voters during the Weimar Republic, historian Julia Sneeringer usefully illustrates that "[1]ived identities of gender, class, ethnicity, [and] age ... are inherently unstable and constantly in competition, existing in a kind of overlapping simultaneity." 8 Sneeringer argues party political discourse "flattened out" the 
complexities of voter identity, targeting one "dominant" characteristic. Faced with the challenges of party politics in the new republic, the SPD underestimated the impact of increasing transnationalism and cooperation between pacifists and Social Democrats in their constituency. Weimar pacifists and Social Democrats often identified concurrently with the party and peace movements, creating moments of cooperation and tension when individuals were forced to prioritize political goals. Party leaders remained willing to compromise pacifist positions in the name of preserving political influence in the unfolding spaces of democracy. Rank and file party members, however, were not so easily persuaded to abandon their pacifist convictions and identify solely with party disciplinary expectations.

Each of the following four case studies features key individuals: Walter Fabian, Gerda Weyl, Gerhart Seger, and Constanze Hallgarten, pacifist Social Democrats or Social Democratic sympathizers whose "lived identities" connected party politics and pacifist agendas. Just as prominent liberal Ludwig Quidde established links between his pacifism and role in the German People's Party (Deutsche Volkspartei-DVP) in the 1890s, pacifists Fabian, Weyl, Seger, and Hallgarten established connections between Social Democracy and pacifism during the Weimar Republic. ${ }^{9}$ Although each activist came from a different social and political background, their behavior reveals significant exchange and cooperation among and between these Left groups and an interest in promoting transnational awareness in that focused arena. These four key activists highlight the changing dynamics between party and pacifists as well as sites of national and transnational tension, beginning with their activities in the No-More-War demonstrations and ending with the transnational peace exhibit in Munich.

\section{PEACE POLITICS IN THE STREET}

As a university student in Berlin, Freiburg, Giessen, and Leipzig between 1920 and 1924, Fabian navigated the permeable space between party and popular politics. Over the course of the Weimar period, he participated in No-More-War demonstrations, taught WILPF vacation courses, and was a member of the DPSt. He also became a member of the German Peace Society (Deutsche Friedensgesellschaft- DFG), one of the largest pacifist organizations in Germany, when it was reestablished in 1919. While completing his thesis on the pacifist philosopher Friedrich Wilhelm Foerster, Fabian recognized a link between pacifism and 
socialism which he applied in his own activism. ${ }^{10}$ He emphasized a "new beginning" for the peace movement in 1919, which was augmented by a new purpose for Weimar pacifists. According to Fabian, the primary tasks for post-World War I activists were to combat the common prewar notion that military conflicts were inevitable and remind German citizens of the dangers of modern warfare- both tasks embraced by participants in the No-More-War rallies. ${ }^{11}$

Weimar activists staged No-More-War demonstrations on the anniversary of the outbreak of World War I in cities across Germany and in international venues. The first public demonstration occurred in Berlin on August 1, 1920, and participants from diverse pacifist organizations planned the event. Although the socialist parties did not officially endorse the 1920 rally, many SPD and USPD members supported No-More-War events by 1921. In fact, Riesenberger attributes the success of these subsequent rallies to the support of the SPD and USPD. ${ }^{12}$ The annual protests, therefore, represent one prominent site where significant numbers of party members and pacifists interacted and core political support proved crucial for success. Between 100,000 and 200,000 individuals participated in the 1921 Berlin rally and approximately 500,000 demonstrated in solidarity across Germany. Fabian estimates 100,000 people packed around him in the Berlin Pleasure Garden (Lustgarten) for a demonstration that had "international character and led to a highpoint of the international peace movement."13 Photos of the Pleasure Garden support the accuracy of Fabian's description. They depict men and women packed shoulderto-shoulder in the approximately five acres between buildings, overflowing into the colonnade of the Old Museum and even standing on nearby statues. ${ }^{14}$

Fabian does not explicitly connect the SPD or socialist labor unions with the dynamic No-More-War protests in his memoirs, although there is significant evidence of a Social Democratic presence. ${ }^{15}$ Prominent signs declaring "No More War!" mix with others in the photos announcing SPD groups among the participants, offering visual confirmation of Social Democratic support in 1921. Party members mingled with informal political actors, including pacifists, and the rallies served their purpose as a reminder of the atrocities of World War I. The No-More-War protests demonstrated both the expansion and strengthening of transnational pacifist networks and informal interaction between pacifists, international feminists, and Social Democrats in the broader arena of German national political culture. ${ }^{16}$ 
Pacifism and Social Democracy blended more explicitly outside Germany in a 1921 Paris memorial service for slain French antimilitarist and Social Democrat Jean Jaurés, which was conducted under the No-More-War banner. Arthur Crispien, a leading Independent Social Democrat who joined the SPD a year later, spoke at the ceremony. His appearance was a powerful symbol of the cooperation between pacifists and socialists in Germany and France, two former World War I enemies that Jaurés had attempted to keep from military conflict before he was assassinated in 1914. From Dortmund to Leipzig, Germans read in their mainstream newspapers about Crispien's appearance, an important transnational event, and the growing popularity of No-More-War activities. ${ }^{17}$

Indeed, newspapers represented a critical publicity instrument for these popular demonstrations, fostering rich exchanges between core and penumbra. Just as in Brockliss and Jones's Habermasian interpretation of the French medical world, media played a key role in Weimar political culture. In Berlin, the main Social Democratic newspaper Vorwärts advertised regularly for the No-More-War demonstration in the weeks prior to the 1921 rally, announcing on July 20 that Social Democrats from greater Berlin "officially" decided on "active participation in the.... peace demonstration 'No-More-War!" The author invited not only all comrades but "all friends of the idea of international understanding" to get involved. ${ }^{18}$ This endorsement encouraged support for the fledgling peace demonstrations, which were already located on the margins of Weimar political culture.

As the demonstration date loomed closer, Vorwärts printed various notices for participants including lists of demonstrations in other German cities and planned SPD speakers for the Berlin rally. A front-page article from July 24, 1921, describing preparations for both German and foreign rallies, is particularly telling. ${ }^{19}$ The publicity committee's combination of German and English, such as "Friedensmeeting," and repeated use of English words textually reflects a transnational awareness between the founders of the British "No More War" movement, among others, and the German "Nie-Wieder-Krieg" demonstrations.

The British monthly publication No More War contains further evidence of cooperation between German No-More-War activists and demonstrators around the world. The February 1922 edition featured an article with the title "No More War:' British, French and German Resisters on One Platform." The article highlighted Martha Steinitz, 
Berlin secretary of the German Union of War Resisters, who traveled to London to promote German and international No-More-War activities. Steinitz's speech "in almost perfect English" caught the attention of British antimilitarists and her vivid description of the "remarkable" series of No-More-War rallies in Germany prompted British activists to plan their own demonstrations. German pacifists were also influenced by descriptions of British activism in No More War. One German mother wrote that she received a copy of the monthly "from an old English friend... [and] was deeply impressed by the contents." In addition, No More War frequently mentioned cross-border interaction between activists including an exchange program that encouraged contact between English and German families "holding similar views" in 1921 and 1922. ${ }^{20}$ Both German Vorwärts and British No More War reports attest to transnational awareness on the Weimar political Left.

The relationship between the SPD and the numerous Weimar-era pacifist organizations nonetheless was capricious. Party leaders frequently focused attention on national political interests at the expense of pacifist goals. Peace historian Reinhold Lütgemeier-Davin observes that despite early Social Democratic enthusiasm for the demonstrations, antimilitarist war veterans' groups gradually took responsibility for organization of the annual No-More-War rallies. Riesenberger attributes the SPD leaders' distance to internal tension over peace mobilization in the newly reunited party and thwarted Social Democratic efforts to expand their role in the No-More-War leadership. ${ }^{21}$ SPD historian Heinrich Potthoff chronicles programmatic shifts in party consciousness which occurred after the USPD joined the SPD in 1922. The 1925 Heidelberg party program reflected this merger with a renewed focus on class struggle and an increasingly "Marxist tone." Potthoff suggests that after 1925 the SPD limited its political focus to the "formal functions of democratic institutions" and the "defense" of Weimar democracy to make the transition for former USPD members smoother. ${ }^{22}$ Ultimately, leading Social Democrats turned their attention inward to the national political core and away from controversial extra-parliamentary pacifist activities in their efforts to preserve the democratic system, which was increasingly under threat.

The Heidelberg program represented party leaders' efforts to unite a broadened spectrum of rank and file Social Democrats under one universal agenda. Internal divisions remained and many Social Democrats continued to support the No-More-War protests. Although there was significantly less publicity for the 1922 rallies than in the previous 
year, Vorwärts printed a notice from the eve of the event that declared the SPD "convincingly in agreement" with the No-More-War organizers. Reports also expressed enthusiasm for rallies in France and England. ${ }^{23}$ This party endorsement linked the rallies to core political culture, lending further credibility to the cause. No-More-War maintained its momentum with demonstrations in more than 200 German cities in $1922 .{ }^{24}$ In 1923, however, crisis struck both Germany and the No-More-War protests. French and Belgian troops occupied the critical Ruhr industrial region and were met by steady passive resistance from local workers. The war-devastated countries intended to force reparations from an already financially distressed German population. Passive resistance to this military intrusion had a heavy price. The continued stagnation of these main industrial, coal-producing regions crippled the economy, leading to inflation and extreme hardship for many Germans.

In this unstable climate, Social Democratic Interior Minister Carl Severing prohibited all public demonstrations and thereby severely limited No-More-War activities. A notice for the annual No-MoreWar rallies appeared on the second page of the July 26, 1923 edition of Vorwärts. As a result of the prohibition, organizers reduced the mass No-More-War Berlin demonstrations of previous years to five small gatherings in closed venues and cancelled outdoor marches. Interested participants needed to pick up tickets distributed in threehour windows the preceding Friday and Saturday at each location. ${ }^{25}$ Although the tickets were free, this new system placed greater responsibility on individual demonstrators. They were now required to plan ahead, choose a venue, and make an additional trip for tickets. Reports in the British publication No More War noted the smaller German meetings were a stark contrast to the highly visible, and considerably more accessible, open-air demonstrations held in previous years. Vorwärts announcements for the demonstrations in 1924 suggest a similar compartmentalized arrangement on both the traditional Sunday afternoon and the following Monday. This controlled environment did not, however, keep German No-More-War organizers from calling for "rallies for world peace in all parts of the country." British reporters also drew attention to the participation of French, German, and English speakers in Berlin rallies. When the police superintendent prohibited Frenchman Paul Langevin from taking the stage at an indoor rally, demonstrators read his prepared speech aloud. ${ }^{26}$ The physical meeting space for transnational pacifist activists was 
restricted, but their anti-war efforts continued to intrude into the wider realm of Weimar political culture.

The No-More-War legacy is both lasting and complex despite some historians' negative assessments. Lütgemeier-Davin considers the No-More-War rallies a failed experiment. He argues that "the peace question as an integration-moment for pacifists, republicans, socialists, and labor organizations" was not successful. ${ }^{27}$ Bessel also grounds his conclusions about the disappointing impact of pacifism on Weimar culture partially in Lütgemeier-Davin's evaluation of the No-MoreWar initiative. By 1925, No-More-War events had indeed lost momentum, and Lütgemeier-Davin correctly argues that the mobilization effort as a formula for lasting official SPD and peace movement cooperation was a disappointment. Pacifists, however, carried on the NoMore-War spirit, Fabian's "high point" of the international peace movement in Weimar Germany, and integrated its battle-cry into other contexts. No-More-War reappeared during the May 1st labor rallies, for instance. Pacifist student leader and Social Democrat Gerda Weyl authored a front-page article in the DPSt's newsletter "Young Pacifists" (Pazifistische Jugend) in 1925 that firmly linked the May 1st "Anti-War Day" with the familiar "No-More-War" call. ${ }^{28}$ These broad uses of the slogan received mixed reviews during the Weimar era. Quidde and mainstream pacifists balked at the broad anti-militarist pacifist message promoted by the No-More-War rallies. However, even Quidde admitted the general appeal of "No More War" lent a certain freshness to the greater pacifist cause, attracting younger participants like Fabian and Weyl. ${ }^{29}$ The legacy of this dramatic collective political action remained alive until the final years of the Republic and even after World War II as participants fondly remembered it as a moment of idyllic international cooperation. ${ }^{30}$

Although SPD support for organized peace activism like the NoMore-War demonstrations drastically diminished over the first half of the 1920s, individual Social Democrats continued to participate in transnational pacifist initiatives. The No-More-War movement provided pacifists with a visible outlet for their convictions. As the demonstrations lost support, organizations such as WILPF and DPSt filled the void with alternative educational programs that drew attention to the importance of peace and transnational cooperation. One of the most effective strategies was the organization of activities such as vacation courses, exhibits, and reading sessions. All three efforts encouraged German citizens, and first-time voters in particular, to 
participate in the new democracy and develop a political awareness that defied national boundaries.

\section{FEMINIST AND PACIFIST NETWORKS IN ACTION}

WILPF groups across Europe hosted international summer and vacation courses in an effort to promote domestic political participation, develop transnational networks, and instill a sense of urgency for international reconciliation among young people. Drawing on its rich tradition of international cooperation among women, WILPF provided a critical framework for pacifist and feminist activism, strengthening connections between German chapters and transnational networks by bringing activists together across national borders. ${ }^{31}$ Historian Jo Vellacott cites interpersonal contacts established in nineteenth-century women's social and suffrage networks as playing a "real and significant role in international understanding." 32 These networks, Vellacott argues, laid critical foundations for what she terms transnational WILPF networks at the end of the nineteenth and beginning of the twentieth century. WILPF leaders built on this tradition of personal networks, organizing vacation courses that would serve as incubators for renewed transnational contact during the 1920s.

In 1923, Fabian and his future wife Dora Heinemann participated in WILPF vacation courses at the University of Geneva in Switzerland. ${ }^{33}$ Fabian remembers this cross-border collaboration warmly, praising both the women's organizations and the DFG for "cultivating international connections" during the Weimar era. Colleague Detlef Oppermann's observation that Fabian's World War II exile experiences were comparatively smoother than others attests to the enduring strength of these connections. Oppermann attributes Fabian's comparable good fortune in exile to his contacts in the former Czechoslovakia, France, and Switzerland, which he nurtured through his Weimar "political position." 34 WILPF courses provided participants such as Fabian with direct personal networking opportunities and fostered a spirit of transnational cooperation. British organizers described these activities best in 1921, dubbing their pedagogical "experiment" in Salzburg "Education for Internationalism." 35

The Salzburg summer school was a success, attracting more than 300 participants from eight countries and territories, including Germany. Teachers conducted sessions in English, French, and German. Though no direct translations were available to students, 
linguistic diversity among the participants provided an opportunity to escape the boundaries of one of the most prominent symbols of individual national identity: native language. ${ }^{36}$ German participant Gertrud Baer described her feelings about the Salzburg school declaring, "International? The world today scoffs at the term and drags it through the mud- but for us it has a lighter, warmer tone; a source of energy for new action!" The "us" in Baer's statement refers to the international group of summer school participants "who got to know one another through their common task," revealing the strength of her identification with these transnational connections. ${ }^{37}$ Baer's enthusiastic report attests to the success of the 1921 session and WILPF expanded offerings in 1922 to include Easter courses in England and two more summer schools, one of which was organized and hosted by the German WILPF branch at the Bavarian castle Lauenstein. ${ }^{38}$ These courses were a welcome outlet for German students frustrated by the largely conservative and nationalist university environment of the Weimar period.

In light of this conservative university culture, Fabian describes the efforts of organizations like the DPSt to sway nonpolitical or conservative university students to the pacifist cause. To this end, Berlin DPSt leader Weyl incorporated transnational pacifist ideas into a successful series of Leseabende (reading sessions) held from 1925 until 1927. A woman of many interests, Weyl's personal biography provides insight into the behavior of a female pacifist Social Democrat in the Weimar Republic. Entangled in various networks of pacifists and socialists in a university environment that was rather unfriendly to both, Weyl worked diligently in pacifist organizations such as the DPSt and the League of Free Socialist Youth (Bund freier sozialistischer Jugend). As a leading student pacifist, she often represented both groups at German Peace Cartel (Deutsche Friedenskartell- DFK) meetings in the 1920s. ${ }^{39}$ In a report on the $1925 / 1926$ winter semester, DPSt national press officer Rudolf Küstermeier recognized Weyl's deep commitment to the organization and her exceptional work. "The best group is apparently Berlin," Küstermeier claimed, "where Gerda Weyl achieved promising improvements as deputy chairman, especially with her pacifist reading sessions." 40

The DPSt needed a rallying point in the turbulent scene of Weimar pacifism. In October 1924, Weyl participated in the DPSt Berlin Conference where the pacifist group formulated a tactical new program that embraced all students "who fight against war as a crime and advocate international cooperation." ${ }^{41}$ Roughly a year later, Weyl 
launched the first reading sessions, encouraging exchanges of information and ideas through a broad range of themed meetings. The series occurred at a critical moment in Weimar history and the history of the DPSt as an organization. The year 1926 marked Germany's acceptance into the League of Nations after years of negotiation and brought a surge in domestic media attention to its activities. ${ }^{42}$ In the midst of these political dialogues, the Berlin DPSt group initiated reading sessions that addressed diverse issues ranging from international arbitration and peace to contemporary social tensions. The meetings were well-publicized and open to all, not just students. ${ }^{43}$

Weyl's initiative was not the first instance of ideological grassroots education in the political penumbra. Historian Jean Quataert's work on early Social Democratic women's programs reveals that reading sessions organized by female Social Democrats in Berlin in the early 1900s were part of a "long-standing commitment to continuous education for [the] rank and file." This "education of all by all" included guided discussions of works such as the Communist Manifesto and various programmatic documents of the SPD. ${ }^{44}$ The Social Democratic tradition of "Women's Meetings" continued even after women gained the right to vote in 1919. These meetings took the form of organized lectures, reading sessions, and other alternative activities to general party meetings, which were characteristically not well attended by female members. ${ }^{45}$ Weyl would have been familiar with the tradition as a young Social Democrat and through her mother, who participated in numerous Berlin Social Democratic women's clubs and social advocacy committees from the turn of the century through the Weimar period. Weyl's placement of the DPSt flier collection with her mother's papers at the Archive of Social Democracy suggests that she linked her own reading sessions with this common Social Democratic practice more explicitly than the documents alone reveal. ${ }^{46}$

The use of the reading session tradition reflects the impact of Social Democratic women's culture on Weyl's activities as a young adult in the 1920s. It was part of her political experience, and this experience affected her daily actions. Although Weyl's sessions targeted a broader and more coeducational audience than traditional women's reading sessions, the focus was nevertheless the same: to convey the groups' message by encouraging an interactive educational experience apart from mainstream political and social rhetoric. These activities took advantage of emerging space in political culture and 
integrated ideas from core party politics as well as transnational pacifist and feminist networks in outlying political arenas.

Gertrud Eysoldt, a prominent actress, teacher, and radio announcer, kicked off the theme "Comrades in Humanity" in October 1926 with her lecture "America and China." Between 1905 and 1934, Eysoldt taught over 2000 students at the German Theater Acting School and was extremely popular with young Berliners. In addition, her biographer, Carsten Niemann, notes that Eysoldt was enamored with new radio technology and was a regular broadcaster in the 1920s. Listeners could tune in to her programs in Germany as well as abroad. Niemann also describes Eysoldt's deep commitment to pacifism and her use of many different venues to promote peace in German society. ${ }^{47}$ Although Eysoldt was a German actress, she drew many ideas from outside German national borders to promote peace and transnational awareness in her broadcasts in Berlin. Her background and deep commitment to peace connected her with DPSt goals, while her international reputation drew attention to the Berlin organization's efforts to promote peace by looking beyond national boundaries.

In preparation for Eysoldt's talk, the DPSt produced fliers in handy half-sheets to publicize the "Comrades in Humanity" event, purposefully highlighting Eysoldt's name in bold, red letters (see Figure 1). The DPSt counted on the actress's popularity to draw a large crowd and her enthusiasm for pacifism and the topic to keep up the momentum for the remainder of the series. ${ }^{48}$ Weyl rode Eysoldt's coattails, scheduling her "Comrades in Humanity: North and South" session exactly two weeks after "America and China." Two weeks later, Rolf Gärtner delivered the third "Comrades in Humanity" installment entitled "The New Russia takes Flight," building on the energy of the previous two events. ${ }^{49}$ Such clever marketing strategies no doubt contributed to the impact of DPSt reading sessions as they sought to expand pacifist activism in Berlin.

Weyl's "North and South" discussion attests to her blending of pacifist, feminist, and transnational ideas in the reading sessions. The title itself suggests a broad nongeographical perspective and the flyer announced that Weyl read from Danish feminist author Karin Michaelis' work as well as from the correspondence of iconic Italian actress, Eleonora Duse. ${ }^{50}$ In this evening session, Weyl encouraged the audience to look beyond German borders to women who challenged the status quo. Michaelis' famous work The Dangerous Age chronicles 


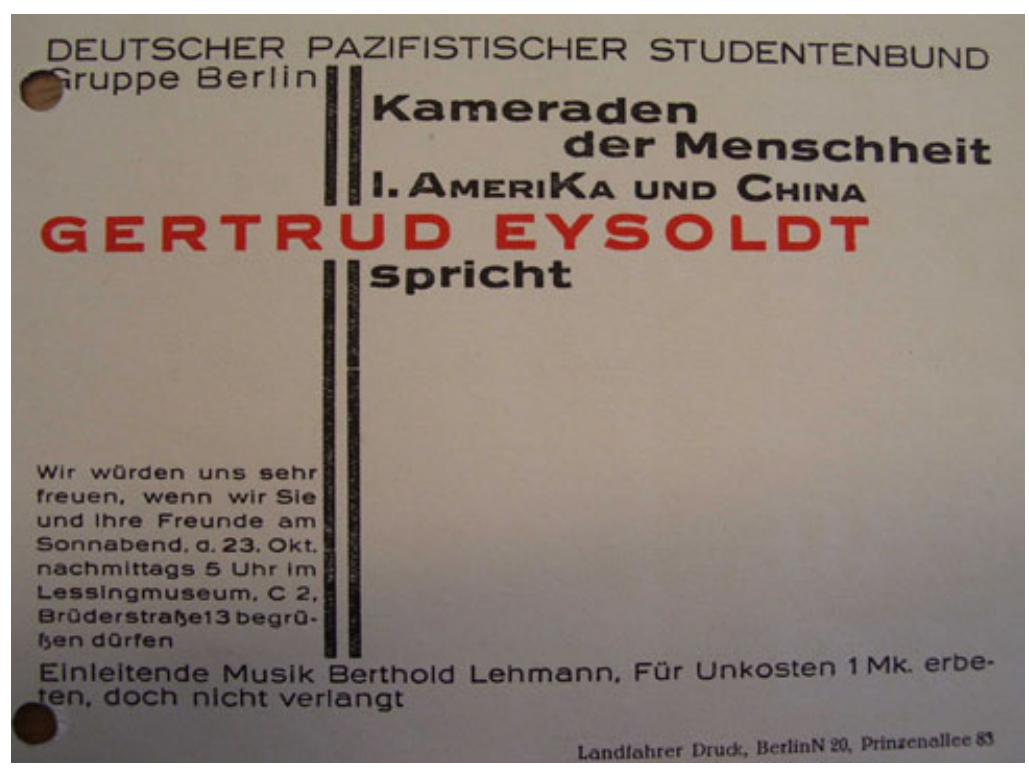

Figure 1. DPSt Flier. Courtesy of League of Nations and Peace Movement Collection, Deutsches Friedenskartell, United Nations Library at Geneva.

the life of a divorced woman at the turn of the century. Biographer Helen Sheehy declares that throughout her acting career Duse "expanded the very idea of Woman" and "she revealed the immense gap between accepted ideas of woman and what a woman really was." "51 These iconic women represented a long tradition of feminist thinking on women's issues often considered private. Weyl drew on their legacies to establish dialogues across national borders based on shared values and to encourage German activists to look outside their own nation for inspiration. Her innovative use of Social Democratic tradition combined with an emphasis on pacifist, feminist, and socialist ideas contributed to the success of the Berlin DPSt in the mid-1920s and reveals the growing potential of peripheral political culture initiatives in Weimar democracy.

Weyl's use of the reading sessions was a distinct and promising effort to promote the goals of the 1926 DPSt program, which called for open international cooperation between students and academics of 
all countries. The DPST explicitly acknowledged its support of Weimar individual and group networks, advocating "a basic reorganization of the relationships of individual person to individual person, group to group and country to country." The fourth program point declared support for the League of Nations and efforts to make it a "true supranational working-group." 52 This point highlights DPSt members' desire to see the League become a more transnational rather than strictly international organization, a goal shared by many Social Democrats who envisioned the League as one of peoples rather than nations. ${ }^{53}$ DPSt members and fellow pacifists, though limited to the periphery of political culture, structured their transnational ambitions carefully in an effort to bring cross-border collaboration and awareness into the larger national political arena. The 1927 Munich peace exhibit further demonstrates the success of transnational pacifist initiatives in breaking out from the limits of both national and political frameworks during the Weimar Republic.

\section{TRANSNATIONAL NETWORKING ON DISPLAY}

The 1927 peace exhibition entitled "Peace Movements and Peace Activism in all Countries" is perhaps the best indicator of the expanding transnational influences in German political culture. This Munich exhibit brought together material from all over the world and traveled to various cities throughout Germany. Hallgarten describes the perseverance of pacifist Marie Zehetmaier as the main catalyst for the project. Failing to gain support from the Munich DFK group, Zehetmaier appealed to Quidde as leader of the DFG because he had been out of town when her exhibit proposal was rejected as too costly. ${ }^{54}$ Zehetmaier's personal agency brought this transnational vision to fruition. With Quidde's aid, Zehetmaier gathered so much material from various international groups in her home that Hallgarten marveled at how she could live "in such a tangled mass of paper." 55 The overwhelming enthusiasm and the speed with which Zehetmaier was able to collect project materials (less than one year) demonstrates the tight links between pacifist networks in Germany and abroad. As a member of the DFK, Hallgarten voted against Zehetmaier's 1926 proposal, yet she could not deny the mounting enthusiasm for the innovative exhibit from both German and international pacifist organizations.

Hallgarten herself represents an intriguing figure in Weimar political culture. A middle-class feminist as well as a pacifist, she insists in 
her autobiography that she never belonged to a political party. Her inclination toward socialism is documented, however, especially at the beginning of the Weimar period when she was a member of the League of Socialist Women (Bund Sozialistischer Frauen). In addition, her biographers note that she voted socialist in the 1919 elections even though her husband voted democratic. Hallgarten's participation in the 1919 WILPF Zürich Conference directly after the war, despite extreme financial hardship and difficult traveling conditions, also demonstrates her dedication as an international activist. In addition, she represented the DFK at the first Munich No-More-War demonstration in 1922, enthusiastically noting the participation of American pacifists in her memoirs. ${ }^{56}$ Hallgarten's activities reveal the extent to which transnational and national political culture intersected in the Weimar era.

The idea for a peace exhibit may have been initiated through the individual efforts of pacifists such as Zehetmaier, Hallgarten, and Quidde, but the trio's combined connections to larger pacifist networks helped make the exhibition a success. Hallgarten reached out to Munich leaders for support and was surprised to find that of the two main religious groups, Catholic officials were more likely to support the initiative than Lutheran. In fact, Hallgarten, a member of the Lutheran church, was deeply disappointed by the intense negative reaction of the clergymen, one of whom mocked not only the idea of peace to her face, but the League of Nations as well. ${ }^{57}$ Interestingly, Hallgarten attributed this difference to a Catholic predisposition to be internationally minded based on the church's supranational structure as opposed to the national structure of the Lutheran church. She surmised that Catholic officials transcribed positive experiences from wider church frameworks to the proposed transnational German peace exhibit and therefore supported the effort. Here, Hallgarten shows a keen awareness of differences between transnational and national perspectives in her own political activities.

Although the Munich DFK officially declined the project, many of its member organizations participated. The three largest exhibit rooms reflected complementary involvement of the DFG, WILPF, and Zehetmaier's religious pacifist organization as main Munich sponsors. ${ }^{58}$ Contributions for the displays came from all over the world. After an entrance exhibit illustrating the costs and horrors of World War I through photographs, artwork, and graphic statistical charts, the organizers dedicated a room solely to the League of Nations. The 
League's Information Section provided extensive materials highlighting its international organization as well as past, present, and future diplomatic work. DFG organizers hoped the League's prominent place in the exhibit would be thought-provoking for visitors and simultaneously pressure League officials to develop the body into "a true instrument of peace," something that many Weimar pacifists, including the DPSt as noted above, advocated. ${ }^{59}$ The first room reflected Weimar pacifists' efforts to remind Germans of the horrific war and the second advocated a solution.

The peace exhibit prominently displayed and celebrated critical moments where pacifists reached across national borders and accepted so-called enemies without prejudice. One way participants in supranational networks demonstrated their international consciousness, according to the historian Leila Rupp, was to "reach out to those [who were] supposed to be ... enemies." 60 WILPF members' efforts to bridge national animosity with personal acts of symbolic "sisterhood" are well-documented in Rupp's Worlds of Women. ${ }^{61}$ A poster captioned "Women from 'Enemy' Countries Meet in Zurich in May 1919" from the exhibit reinforces the point (see Figure 2). It displayed a collage of photographs taken at the 1919 WILPF meeting and further emphasized the lasting impact of these conscious acts of transnational cooperation as well as the pride felt by participants. ${ }^{62}$

At the time, women from across the globe had gathered in Zurich to protest the harsh peace treaty terms simultaneously under discussion in Versailles. Vellacott emphasizes the contrast between the female Hague delegates in 1919 brought together by "a shared and terrible experience of war" and the statesmen at Versailles. Instead of focusing on preventing war, these men "thought in terms of retribution, of gains, of enforcement, of maintaining the upper hand," Vellacott argues. "[I]ndividually, each worked for the perceived advantage of his own country." 63 WILPF delegates to the 1919 meeting built upon foundations laid by the International Committee of Women for Permanent Peace at The Hague, and their feminist networks remained grounded in the same spirit of conscious transnational cooperative action throughout the Weimar period. ${ }^{64}$ The poster's designers captured this moment of purposeful female solidarity, presenting photographs of women from various countries, including prominent German personalities Anita Augspurg, Lida Gustava Heymann, and Hallgarten. The photos vividly display transnational 


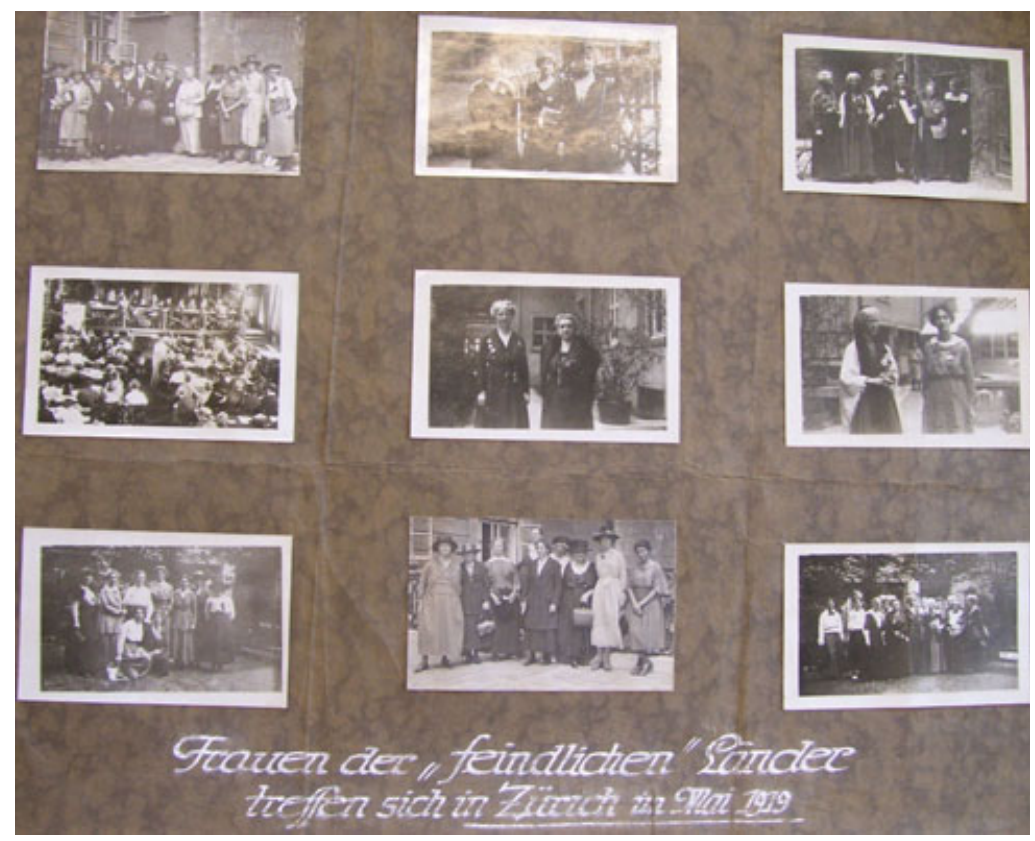

Figure 2. "Women from 'Enemy' Countries Meet in Zurich in May 1919." Courtesy of League of Nations and Peace Movement Collection, Deutsches Friedenskartell, United Nations Library at Geneva.

interpersonal contact by including women of several nationalities as subjects (see Figure 3). The emphasis was the product of conference participants' efforts to demonstrate international female solidarity in 1919 as well as the pride of Hallgarten and exhibit organizers to illustrate this moment of true transnational cooperation. After all, Vellacott reiterates, "war requires an enemy, and it is hard to consider as enemies those you know well." 65 The poster format was a conscious demonstration of transnationalism in both moments, one example of many throughout the exhibit.

The focal point of the peace exhibit, a large sarcophagus, represented another symbol of purposeful transnational solidarity among the displays. In Munich, the casket "ruled" the stage of the exhibit hall where Quidde, a transnationally recognized figure, had laid a golden laurel wreath on it. A nearby sign displayed the words "To all 


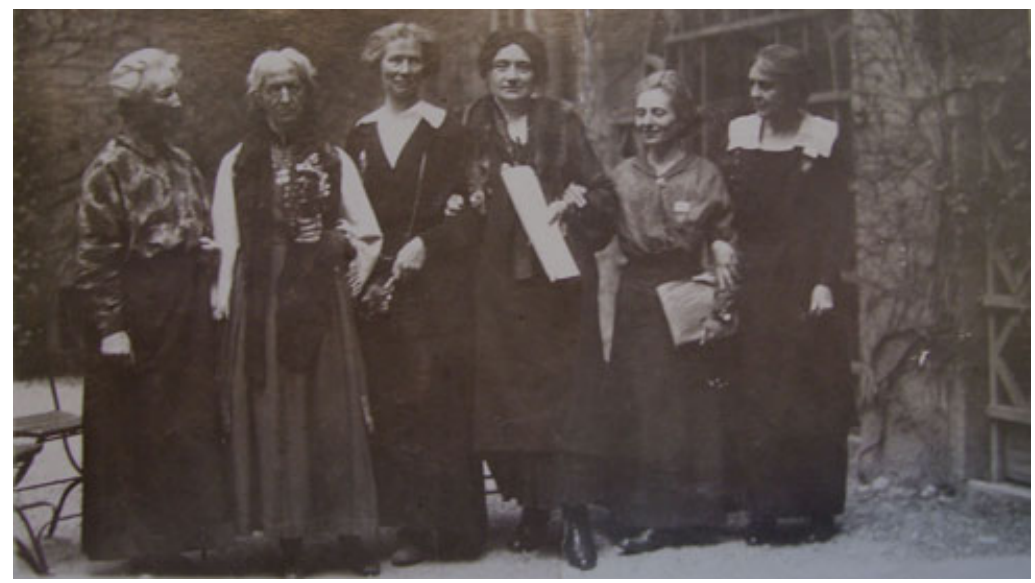

Figure 3. Close up from “Women from 'Enemy' Countries Meet in Zurich in May 1919.” From left to right: Anita Augspurg (Germany), Charlotte Despard (Great Britain), Lida Gustava Heymann (Germany), Rosa Genoni (Italy), Leopoldine Kulka (Austria), Andrée Jouve (France). Courtesy of League of Nations and Peace Movement Collection, Deutsches Friedenskartell, United Nations Library at Geneva.

those who died for their country 1914-1918." "66 This gesture demonstrated a tremendous effort toward international reconciliation and recognized suffering on both sides of the battlefield. The sarcophagus display revisited the earlier tentative effort to equate the experiences of all victims of aggression, which international feminists and pacifists had grappled with in transnational discussions of the 1922 No-MoreWar demonstrations. ${ }^{67}$ By 1927, however, Quidde boldly used this symbol to invoke a sense of common experience and brotherhood with foreign soldiers and their families. The sarcophagus featured in several DFG announcements for the exhibit, with authors often stressing the transnational solidarity represented by the display. Quidde's efforts were meant to have visual shock value as well as educational merit, causing Germans to think about similarities between themselves and victims of war in every nation.

Despite DFK misgivings, the peace exhibit was a hit, launching from its Munich base and traveling in 1927 and 1928 to the German cities of Würzburg, Erfurt, Harburg, and Dresden. The exhibit drew 
many school classes, and visitors came "again and again" to view the displays. ${ }^{68}$ What started as a local pacifist's vision of bringing transnational awareness to Munich transformed into a national exhibit, which itself attracted notice within and beyond German borders. ${ }^{69}$ This exhibit was indeed a site of transnational exchange in German political culture. It represents a rich moment of cooperation between pacifists, Social Democrats, and feminists as they worked together to bring transnational awareness to their own regions.

Gerhart Seger, the General Secretary of the DFG and later SPD representative to the Reichstag, traveled from Berlin to help prepare the exhibit and generate publicity. Seger also spoke on the destructive potential of future wars in the evening lecture series held in tandem with the Munich exhibition. ${ }^{70}$ Although the lecture series poster did not explicitly identify Seger with the SPD, his presence and participation suggest that party officials did not actively block him from publically supporting a pacifist agenda. In fact, Seger was not unique. Reports in the WILPF publication Völkerversöhnende Frauenarbeit from December 1928 claimed that Dresden WILPF members, many of whom were Social Democrats, brought the peace exhibition to their city. In the same report, the WILPF group in Darmstadt boasted of great support for their publicity campaigns from Social Democratic publicists. ${ }^{71}$ Even though the SPD withdrew official support from peace organizations in the mid-1920s, individual party members maintained connections between formal politics and penumbra political activities in the pursuit of peace.

\section{POLITICAL LITMUS TEST}

Despite these examples of cooperation and intersection, the pacifist milieu and Social Democracy were put to the test in 1928. After an intense election campaign that promised "food for children" instead of funding for new Panzerkreuzer (battleships), Social Democratic cabinet members turned their backs on the campaign promise and their own party colleagues. The ministers supported the ship construction project, believing they had made a logical compromise by allowing the battleships to be built and preserving political harmony in a fragile coalition government. ${ }^{72}$ SPD historian Donna Harsch observes, however, that the "decision unleashed a storm of protest in the SPD more intense than any since the [1918/1919] revolution.",73 
A key part of Social Democrats' disappointment in their ministers derived from the recent 1928 election campaign against rearmament. SPD candidates from all levels jumped on the controversial issue, fueling the fire with slogans critiquing battleship supporters' efforts to prioritize funds for weapons over the basic needs of the population. The campaign was in large part successful, gaining the SPD more than twenty new Reichstag seats. There was a strong pacifist presence in the party by 1928, in part thanks to the merger with the USPD, and peace historian Karl Holl notes that the majority of organized pacifism rejected the proposed battleships. ${ }^{74}$ Harsch evaluates the general appeal of the slogan, stating that it added "spice" to SPD propaganda and tapped into the "antimilitarism [that] was a potent ingredient in the Social Democratic worldview." "75 Campaign rhetoric drew attention to party antimilitarism and social welfare concerns during the election, intensifying the contrast between campaign promises and the ministers' actions once in office.

Outcry from all ranks of the SPD and peace organizations flooded newspapers and dominated meeting minutes within days of the battleship vote. Pacifist convictions as well as a strong belief in party discipline and upholding electoral promises drove many party members and supporters to denounce the decision and demand greater accountability for the SPD ministers' actions. Social Democrats, pacifists, and feminists who had collaborated successfully on Weimar educational and protest activities were outraged by this controversy. Fabian called for the SPD to leave the governing coalition and mobilize popular political opposition against the battleship construction akin to the NoMore-War protests. ${ }^{76}$ In a DFG press release outlining the group's objections, secretary Seger declared the decision not only represented "the beginning of rearmament" but was "a slap in the face of the voting masses." 77

The SPD ministers' decision was severely disillusioning from the perspective of many party sympathizers and members. Pacifist Social Democrat Heinrich Ströbel fumed that the incident revealed "all the [Social Democratic] disarmament and No-More-War talk" as "blue smoke and world peace as a soap bubble." ${ }^{, 78}$ In addition, grassroots education efforts meant to empower new voters were all for naught if elected leaders ignored those newfound voices. True to Fabian's call for popular protest, pacifist groups organized public events in the weeks after the crisis began. The DFK organization, the German League for Human Rights, for example, hosted an event entitled 
"Panzerkreuzer, the People's Will and the Government" on August $24 .^{79}$ These dissident voices, fostered by the sustained promotion of transnational awareness, culminated in demands for a people's referendum to take matters into their own hands.

Intense reactions to the battleship scandal were not limited to the political penumbra. Party members across the ranks were equally outraged by the actions of their ministers. The 1929 Magdeburg party meeting was fraught with arguments that party discipline had broken down and the ministers were out of line. Cabinet member Hermann Müller claimed he never personally uttered the much-criticized campaign promise. Other speakers passed the blame around from the ministers to party opposition, and even to the voters who did not muster enough support to create a cabinet with a Social Democratic majority. ${ }^{80}$ Despite these disagreements, representatives at the meeting produced the "Guidelines for Military Policies" (Richtlinien zur Wehrpolitik). The guidelines emphasized the SPD's position against war as an instrument of diplomacy and sought the democratization of the League of Nations. Social Democrats envisaged the diplomatic organization as a league of peoples rather than a league of states so that it could become an "effective instrument of peace." Defensively, the guidelines reaffirmed SPD foundations in transnational ideas of international socialism stating, "[s]ocialism is the power that will bring the world lasting peace." 81

Many historians cite the battleship scandal as a massive breakdown in SPD party organization and, especially for Harsch, one moment that could be considered the beginning of the end for Social Democrats in the Weimar Republic. The scandal represents much more than inner-party strife and the breakdown of party and pacifist cooperation, however. The outcry against the ministers' decision from all corners of the German Left is particularly telling. As Potthoff notes, SPD leaders began to look inward for solutions to broader problems of Weimar democracy after 1925. They failed to consider that pacifism and international understanding had become a common language among many participants in core and penumbra political culture as well as national and transnational networks. The issue even attracted attention outside German borders. Dutch Social Democrat Dr. Johan Willem Albarda wrote to Müller about the reaction to the scandal in the Netherlands: "[w]hen we held a number of demonstrations for disarmament on September 16 the streets were covered with huge signs with Panzerkreuzer!" 82 The scandal, therefore, can be seen 
as a litmus test for subtle changes in political consciousness on the German Left. It reveals expanding transnational awareness in the national arena and sites of tension between SPD leaders and individual activists. Furthermore, the scandal illustrates the impact of national events beyond delineated borders.

\section{CONCLUSION}

This examination of pacifists, Social Democrats, and feminists reveals that the "echo" of pacifism in Weimar political culture is worth further consideration. Fueled by wartime experiences, these social actors built on pre-existing transnational networks and embraced ideas, awareness, and cooperation from beyond national borders. SPD members such as Fabian, Seger, and Weyl openly participated in pacifist activities, exchanging ideas, developing transnational connections, and, as Baer proclaimed, rallying around a sense of international responsibility. Their participation in pacifist initiatives opened up new political space in Weimar politics, normalizing cooperation between Social Democrats and pacifists through individual interaction. The battleship scandal refocused attention on a key problem for Social Democratic leaders: voter awareness was evolving and they needed to acknowledge the impact of these changes, including increasing transnational pacifist influences, to be effective in the political arena. The peace party was once again in conflict with its constituency.

Eerily similar to the party truce over war credits, political tensions in 1928 triggered a limited, and in the eyes of pacifists, empty response from SPD leaders, who turned inward for the sake of party stability rather than recognizing increasingly effective grassroots efforts to shape Weimar political culture. In stark contrast, initiatives such as the NoMore-War protests, WILPF vacation courses, DPSt reading sessions, and the 1927 peace exhibition promoted transnational networks and cooperation in an environment notorious for fostering rising nationalism and militarism before 1933. These case studies reveal a visible layer of pacifist activity in the Weimar Republic that has been obscured by scholarly attention to the rise of National Socialism and the collapse of the Republic. Despite increasing limits on political activism, the development of new political space between core and periphery fostered by individual cooperation on the Left during the Weimar Republic helped lay the groundwork for transnational interaction and peace politics in postwar German political culture. 


\section{NOTES}

I would like to thank the editors and two anonymous reviewers for Peace \& Change as well as Jean Quataert, Jaime Wadowiec, and Stewart Anderson for their critical comments and suggestions for this article.

1. Richard Bessel, Germany after the First World War (Oxford: Oxford University Press, 1993), 262. In my understanding, political culture consists of any activity intended to influence the course of formal national, or transnational, politics. These activities include publicity campaigns, educational efforts, and popular mobilizations as well as more concrete interaction between individuals or grass-roots organizations with established political institutions, such as political parties and their representatives.

2. Jennifer A. Davy, ''Manly' and 'Feminine' Antimilitarism. Perceptions of Gender in the Antimilitarist Wing of the Weimar Peace Movement" in Frieden-Gewalt-Geschlecht. Friedens- und Konfliktforschung als Geschlechterforschung, eds. Jennifer A. Davy, Karen Hagemann and Ute Kätzel (Essen: Klartext, 2005), 164-165. Margaret Anderson argues there were important democratic continuities from Imperial German political culture which spanned the caesura of war and revolution, including the practice of electoral politics. See Anderson, Practicing Democracy: Elections and Political Culture in Imperial Germany (Princeton: Princeton University Press, 2000), 426.

3. These crossroads are the primary focus of my analysis and provide insight into a specific cross-section of German political culture. An overview of the complexities of Weimar political culture as a whole is beyond the scope of this article. I define transnational as a descriptive term which refers to interand non-governmental networks, ideas, contacts, and organizations active outside the boundaries of a single nation-state. Historical transnational analysis pursues an awareness and recognition of these supranational forces as factors which affected social actors and their immediate environment at critical moments in history.

4. See Brockliss and Jones, The Medical World of Early Modern France (New York: Clarendon Press, 1997), Introduction.

5. Dieter Riesenberger, Geschichte der Friedensbewegung in Deutschland von den Anfängen bis 1933 (Göttingen: Vandenhoeck \& Ruprecht, 1985), 86. A class-based understanding of peace embraced by SPD leaders is the main cause of this tension according to Riesenberger. The peace party debate attracts attention even after Weimar. Michael Longerich chronicles this phenomenon in his monograph Die SPD als "Friedenspartei" -mehr als nur Wabltaktik? (Frankfurt a. M.: Peter Lang, 1990). 
6. I will specify which Social Democrats belonged to, or sympathized with the USPD during its existence. My overall analysis focuses on Social Democrats from the SPD including several USPD members who rejoined the SPD in 1922. For a useful discussion on political parties and the effects of shifting milieus in German politics see Karl Rohe, ed., Elections, Parties and Political Traditions: Social Foundations of German Parties and Party Systems, 1867-1987 (New York: Berg, 1990), Introduction.

7. Helmut Donat and Johann P. Tammen, eds., Friedenszeichen, Lebenszeichen. Pazifismus zwischen Verächtlichmachung und Rehabilitierung. Ein Lesebuch zur Friedenserziehung (Bremerhaven: Wirtschaftsverlag NW Verlag für neue Wissenschaft, 1982), 229.

8. Julia Sneeringer, Winning Women's Votes: Propaganda and Politics in Weimar Germany (Chapel Hill: University of North Carolina Press, 2002), 7. Rohe also emphasizes the importance of individual choice in political behavior. See Rohe, Elections, Parties and Political Traditions, 22.

9. These four individuals were not the first to negotiate both party political and peace movement activism. See Riesenberger's description of how Quidde attempted to balance his leadership role in the DVP with his peace activism in 1893. Riesenberger, Geschichte der Friedensbewegung, 58. Biographers document Constanze Hallgarten's socialist sympathies even though she never joined a party. Detlef Garz and Anja Knuth, Constanze Hallgarten. Porträt einer Pazifistin (Hamburg: Verlag DR. KOVAČ, 2004), 38. Weyl and Seger were members of the Independent Social Democratic Party (USPD) during the first few years of the Weimar republic. The USPD reunited with the SPD in 1922.

10. Detlef Oppermann, "Walter Fabian (1902-1992). JournalistPädagoge-Gewerkschafter," Gewerkschaftliche Monatshefte 54, No. 7 (2003): 410-413. Fabian joined the SPD in 1924 and was in Dresden after 1928.

11. Anne-Marie Fabian, Walter Fabian, Arno Behrisch, et al., Arbeiterbewegung, Erwachsenenbildung, Presse: Festschrift für Walter Fabian zum 75. Geburtstag (Cologne: Europäische Verlagsanstalt, 1977), 228-231. Donat and Tammen, Friedenszeichen, 169.

12. Riesenberger, Geschichte der Friedensbewegung, 134. The SPD and USPD often found themselves working towards similar political goals although they remained separate parties until 1922.

13. Reinhold Lütgemeier-Davin, "Basismobilisierung gegen den Krieg: Die Nie-Wieder-Krieg-Bewegung in der Weimarer Republik" in Pazifismus in der Weimarer Republik, ed. Karl Holl and Wolfram Wette (Paderborn: Schöningh, 1981), 53-54, 57-60. Lütgemeier-Davin " $>>N i e-W i e d e r-K r i e g<<$ Bewegung" in Die Friedensbewegung. Organisierter Pazifismus in 
Deutschland, Österreich und in der Schweiz, ed. Helmut Donat and Karl Holl (Düsseldorf: Econ Taschenbuch Verlag, 1983), 286. Donat and Tammen, Friedenszeichen, 172.

14. Holl and Wette, Pazifismus in der Weimarer Republik, cover photo "Pazifistische Massenkundgebung im Berliner Lustgarten anläßlich des Jahrestages des Ausbruchs des Ersten Weltkrieges, 31. Juli 1921.” These impressive attendance estimates can be compared to the 400,000 West Germans who rallied on June 10, 1982 against nuclear weapons in one of the largest Cold War peace demonstrations in Bonn. See Steve Breyman, Why Movements Matter: The West German Peace Movement and U.S. Arms Control Policy (Albany: State University of New York Press, 2001), 106.

15. Donat and Tammen, Friedenszeichen, 229.

16. Lütgemeier-Davin, "Basismobilisierung," 47.

17. Harvey Goldberg, The Life of Jean Jaurés (Madison, WI: University of Wisconsin Press, 1962), 458-472. Lütgemeier-Davin, "Basismobilisierung," 56, 64. News of Crispien's speech reached Germans through major newspapers such as the General-Anzeiger für Dortmund und die Provinz Westfalen and the Leipziger Volkszeitung. Social Democrats Rudolf Breitscheid and Toni Sender spoke at subsequent Jaurés events.

18. “Nie Wieder Krieg!,” Vorwärts (July 20, 1921).

19. Aktionausschuss Nie Wieder Krieg, "Nie Wieder Krieg!," Vorwärts (July 24, 1921); “Nie Wieder Krieg!," Vorwärts (July 25, 1921); “Wer von der SPD spricht am Sonntag, den 31. Juli, auf der Kundgebung, Nie Wieder Krieg?," Vorwärts (July 28, 1921); Aktionausschuss Nie Wieder Krieg, "Nie Wieder Krieg!,” Vorwärts (July 30, 1921).

20. Lütgemeier-Davin highlights the organization of rallies in France, Germany, and England in “Basismobilisierung,” 56. “'No More War:' British, French and German Resisters on One Platform," No More War: The Monthly Organ of the No More War International Movement (February 10, 1922). "Visit of English War Resisters to Germany," No More War (March 10, 1922). “A German Woman's Moving Appeal,” No More War (December 1922).

21. Lütgemeier-Davin, "Basismobilisierung," 63. Riesenberger, Geschichte der Friedensbewegung, 136. According to Riesenberger, SPD leaders sought to expand their role in the No-More-War committee. Failing to do so, they distanced the party from the movement.

22. Heinrich Potthoff and Susanne Miller, Kleine Geschichte der SPD 1848-2002 (Bonn: Dietz, 2002), 120-122. The party struggled to redefine itself after it merged with the USPD, culminating in the 1925 party program.

23. “Nie Wieder Krieg,” Vorwärts (July 30, 1922). 
24. Riesenberger, Geschichte der Friedensbewegung, 134.

25. "Die Friedensfeiern am nächsten Sonntag," Vorwärts (July 26, 1923).

26. "The Demonstrations Abroad," No More War (September 1923). WILPF and general SPD activities were also limited during this period. "Nie wieder Krieg," Vorwärts (July 31, 1924), “Nie wieder Krieg," Vorwärts (July 23, 1924). Lütgemeier-Davin, "Basismobilisierung," 67. Lütgemeier-Davin notes the general fear that opposition from right-wing groups would lead to violence during the demonstrations.

27. Lütgemeier-Davin, "Basismobilisierung," 63.

28. Lütgemeier-Davin, "Basismobilisierung," 68-76. Gerda Weyl, “Zum Anti-Kriegstag 1. Mai 1925," Pazifistische Jugend (May, 1925): 1. The DFG carried the institution still further, publishing an annual special issue with the title Nie-Wieder-Krieg until 1932. Riesenberger notes that when Social Democrats were stymied in their effort to take control of the No-More-War demonstrations they moved on to alternative commemorations, such as traditionally Socialist May 1st rallies. Riesenberger, Geschichte der Friedensbewegung, 136.

29. Riesenberger, Geschichte der Friedensbewegung, 145.

30. Donat and Holl, Die Friedensbewegung, 288.

31. See Leila Rupp, Worlds of Women: The Making of an International Women's Movement (Princeton: Princeton University Press, 1997) for more information.

32. Jo Vellacott, "Putting a Network to Use: Formation and Early Years of the Women's International League for Peace and Freedom," in Politische Netzwerkerinnen. Internationale Zusammenarbeit von Frauen 1830-1960, ed. Eva Schöck-Quinteros, Anja Schüler, Annika Wilmers and Kerstin Wolff (Berlin: Trafo Verlag, 2007), 135.

33. Charmian Brinson, The Strange Case of Dora Fabian and Mathilde Wurm (Berne: Peter Lang, 1997), 107. Heinemann and Fabian were members of DPSt until early 1923. League of Nations and Peace Movement Collection (hereafter LNPMC), Deutsches Friedenskartell (hereafter DFK), UN Library at Geneva, Box 130, File 5: Walter Medding (DPSt) to Katharina Kupsch (DFK), January 23, 1923.

34. Donat and Tammen, Friedenszeichen, 171. Oppermann, "Fabian," 415. Fabian's participation in transnational pacifist networks no doubt helped establish some of these connections.

35. LNPMC, DFK, UN Library at Geneva, Box 131 File 1: Bulletin of the Women's International League for Peace and Freedom (February, 1922): 4 . 
36. Ibid.

37. Gertrud Baer, "Die Internationale Sommerschule in Salzburg," Die Frau im Staat (October, 1921): 6, 8.

38. Bulletin of the Women's International League for Peace and Freedom, 5.

39. See Reinhold Lütgemeier-Davin, Pazifismus zwischen Kooperation und Konfrontation. Das Deutsche Friedenskartell in der Weimarer Republik (Cologne: Pahl-Rugenstein Verlag, 1982), 58-61, 91-92. The German Peace Cartel was an umbrella pacifist group founded in 1921. Weyl appeared in DPSt leadership ranks in 1923 after she joined the SPD. Albert Einstein Archive, Document Number [44-647]: Gerda Weyl (DPSt) to Albert Einstein, May 18, 1923. A police report in Düsseldorf estimates a total of nine DPSt university groups and approximately 500 members in February 1922. Landesarchiv NRW, Abteilung Rheinland, Standort Düsseldorf, Regierung Düsseldorf 15590, Blatt 9 "Auszug aus dem Lagebericht vom 16. Februar 1922."

40. LNPMC, DFK, UN Library at Geneva, Box 130, File 5: Rudolf Küstermeier, "Tätigkeitsbericht des Deutschen Pazifistischen Studentenbundes für das Winter-Semester 1925-26," Special Edition of Die Friedenswarte 26.

41. Lütgemeier-Davin, Pazifismus, 59.

42. Christoph Kimmich, Germany and the League of Nations (Chicago: University of Chicago Press, 1976), 100.

43. LNPMC, DFK, UN Library at Geneva, Box 130, File 5: "Deutscher Pazifistischer Studentenbund Gruppe Berlin Veranstaltungen im Wintersemester 1926-27." The DPSt frequently sent publicity to the DFK. It is included in File 5 referenced above.

44. Jean Quataert, Reluctant Feminists in German Social Democracy, 1885-1917 (Princeton: Princeton University Press, 1979), 193, 195.

45. Karen Hagemann, Frauenalltag und Männerpolitik. Alltagsleben und gesellschaftliches Handeln von Arbeiterfrauen in der Weimarer Republik (Bonn:Verlag J.H.W. Dietz, 1990), 593-595.

46. Ibid, 74 and Archiv der sozialen Demokratie, Friedrich Ebert Stiftung, Bonn (hereafter AdsD), NL Weyl, Document 78: Sydney Strong, "Berlin's Fight with Disease and Poverty," February 1, 1923. The DPSt fliers make up the majority of Gerda Weyl's papers in the AdsD. A significant portion of Weyl's personal papers are housed in the Stadtarchiv Celle implying that she intentionally placed the DPSt flyers at the Ebert Stiftung.

47. Carsten Niemann, "Das Herz meiner Künstlerschaft ist Mut" Die Max-Reinhardt-Schauspielerin Gertrud Eysoldt (Hannover: Theatermuseum und -archiv der Niedersächsischen Staatstheater, 1995), 19, 80, 83. 
Interestingly, Eysoldt had contact with prominent Social Democrat August Bebel as a child.

48. LNPMC, DFK, UN Library at Geneva, Box 130 File 5: "Kameraden der Menschheit I. Amerika und China," October 23, 1926. On Eysoldt's work with youth see "Gertrud Eysoldt," Die Frau im Staat (May, 1925): 11. I have not yet located any attendance figures for the Leseabende.

49. AdsD, NL Weyl, Document 51: "Kameraden der Menschheit," November 6, 1926.

50. Ibid.

51. Karin Michaelis, The Dangerous Age: Letters and Fragments from a Woman's Diary (New York: J. Lane Co., 1912). Helen Sheehy, Eleonora Duse: A Biography (New York: Alfred A. Knopf, 2003), 5.

52. LNPMC, DFK, UN Library at Geneva, Box 130 File 5: "Der Deutsche Pazifistische Studentenbund."

53. For more information on Social Democratic views of the League of Nations see Vincent Sheridan, "The German Social Democratic Party and the League of Nations during the Weimar Republic, 1918-1933" (Ph.D. diss., Arizona State University, 1975). Social Democrats advocated a more democratic organization of the League of Nations which would be truly a league of peoples rather than nation-states and their representatives.

54. Constanze Hallgarten, Als Pazifistin in Deutschland (Stuttgart: Conseil-Verlag, 1956), 70-71.

55. Ibid, 71.

56. Garz and Knuth, Porträt einer Pazifistin, 38, 42. Hallgarten, Als Pazifistin, 50-51.

57. Hallgarten, Als Pazifistin, 72. For more on Lutheran nationalism see Roger Chickering, Imperial Germany and the Great War, 1914-1918 (Cambridge: Cambridge University Press, 2003), 126-129.

58. LNPMC, DFK, UN Library at Geneva, Box 138 File 4.2: Gerhart Seger, "Die erste deutsche Friedensaustellung," Die Friedensbewegung (May, 1927), 19.

59. Ibid and LNPMC, DFK, UN Library at Geneva, Box 138 File 4.5: Käthe Kupsch, "Die Friedensaustellung in Harburg," Harburger Volksblatt (January 21, 1928).

60. Rupp, Worlds of Women, 118.

61. Ibid, 117-121.

62. LNPMC, DFK, UN Library at Geneva, Oversize Photo: "Frauen der 'feindlichen' Länder treffen sich in Zürich in Mai 1919.'

63. Vellacott, "Putting a Network to Use," 148-149. 
64. Olga Knischewsky, "Der Internationale Frauenkongress in Zürich," in Die Frau im Staat (May/June, 1919): 3. Rupp, Worlds of Women, 26-30. These women's networks were very much part of post-World War II women's organizations and instrumental to integrating women into the new United Nations agenda on human rights.

65. Vellacott, "Putting a Network to Use," 153.

66. Seger, "Die erste deutsche Friedensaustellung,"19 and LNPMC, DFK, UN Library at Geneva, Box 138 File 4.2: Ludwig Quidde, "Eine Pazifistische Ausstellung," April 22, 1927. The sign read "Allen, die für ibr Vaterland gestorben 1914-1918."

67. "Nie Wieder Krieg," Die Frau im Staat (July/August, 1922): 21. “The Demonstrations Abroad," No More War (September 1923).

68. Hallgarten, Als Pazifistin, 74.

69. LNPMC, DFK, UN Library at Geneva, Box 138, Files 4 and 5. Few international requests for the exhibit were filled because of financial constraints. In fact, the exhibit accrued a large debt. Hallgarten, Als Pazifistin, 75. The intense cooperation between feminists, pacifists, and Social Democrats in the Munich exhibit makes it of particular interest for this transnational study. Ernst Friedrich organized similar anti-war exhibits during the Weimar Republic and also accrued large debts. A donation from a Swedish pacifist made his creation of a permanent exhibit at the Anti-War Museum in Berlin possible. See Wilfried Knauer, "Ernst Friedrich" in Die Friedensbewegung, eds. Donat and Holl, 152-154.

70. Hallgarten, Als Pazifistin, 73-4. LNPMC, DFK, UN Library at Geneva, Box 138 File 4.2: "Ausstellung Friedenbewegung und Friedensarbeit in Allen Ländern Abendvorträge,” April 22- May 8, 1927.

71. League of Nations Brochure and Pamphlet Collection, Associations Pacifistes Federalisme (DB), UN Library at Geneva, Box 41, Folder 13-14: Internationalen Frauenliga für Frieden und Freiheit Deutscher Zweig, Völkerversöhnende Frauenarbeit, Januar 1926-Dezember 1928 (Munich, c.1928): 15 .

72. AdsD, NL Carl Severing, Mappe 147, Article 41: "Kampf um den Panzerkreuzer: Im Reichskabinett-Eine ungenügende Erklärung- Unruhe in der Partei," Rheinische Zeitung (August 14, 1928).

73. Donna Harsch, German Social Democracy and the Rise of Nazism (Chapel Hill: University of North Carolina Press, 1993), 46.

74. Karl Holl, Ludwig Quidde (1858-1941). Eine Biografie (Düsseldorf: Droste Verlag, 2007), 412.

75. Ibid, 40-1, 46. During the previous government, leading Social Democrat Otto Braun worked diligently to block the construction proposal and it lay stagnant in the political realm until after the election. 
76. Ibid, 47.

77. LNPMC, DFK, UN Library at Geneva, Box 129, File 3: Seger, “Gegen den Panzerkreuzer!” August 13, 1928.

78. Lothar Wieland, “Wieder wie 1914!” Heinrich Ströbel (1869-1944). Biografie eines vergessenen Sozialdemokraten (Bremen: Donat Verlag, 2009), 242.

79. LNPMC, DFK, UN Library at Geneva, Poster Collection, Folder 12, Item 153: "Panzerkreuzer, Volkswille und Reichsregierung," August 24, 1928.

80. Protokoll Sozialdemokratischer Parteitag Magdeburg 1929 vom 26. Bis 31. Mai in der Stadthalle (Bonn-Bad Godesberg: Dietz, 1974), 79-81.

81. Ibid, 289. For more on the League debate see Sheridan, "The German Social Democratic Party and the League of Nations," 149.

82. AdsD, NL Müller, Signatur 1/HMAG00034, IV, Document 2: Dr. J. W. Albarda to H. Müller, September 27, 1928. 